УДК $316.44: 378$

\title{
СОЦИАЛЬНАЯ МОБИЛЬНОСТЬ В СОВРЕМЕННОМ ОБЩЕСТВЕ: ОСНОВНЫЕ ТЕНДЕНЦИИ
}

\author{
(ㄷ) 2012 г. В. С. Любченко
}

\section{Южно-Российский государственный технический университет (НПИ)}

Рассматриваются основные факторы, определяющие характер сочииальной мобильности в современном обществе. Исследуется влияние интеллектуального ресурса на экономическое положение индивида и его жизненные шансы.

Ключевые слова: современное общество; социальная мобильность; ресурсный подход; личностньй ресурс.

In the article author reviews some basic factors, which determine the specificity of the nowadays society members'social mobility. The ways of affecting the individual's economic conditions and his life chances by the intellectual resource is also analyzed.

Key words: the nowadays society; social mobility; resource approach; personal resource.

Существовавшая еще несколько десятилетий назад социальная система, представленная в концепциях функционализма, отличалась стабильностью, поскольку в ней индивиды имели существенные различия в своих личностных ресурсах - в образовательном, культурном, социальном капитале, что позволяло им занять определенную социальную нишу и не давало возможности на равных конкурировать за более высокий социальный статус. В современном социуме произошли значительные изменения. Сейчас важнейшим ресурсом становится образование. Возрастает степень его доступности, вследствие чего многократно возросла конкуренция за наиболее престижные места. В связи с этим нарастает темп социальных изменений, риски, растет неустойчивость социальной системы в целом.

Важнейшим фактором социальной жизни и социальных изменений является в настоящее время изменение роли интеллектуального ресурса в обществе. Наиболее ценным качеством становится способность создавать новации, «ноу-хау». На второй план отходит владение собственностью и принадлежность к высокостатусному слою. Все это привело к тому, что за последние три десятка лет общество в развитых странах претерпело значи- тельные изменения, которые нашли свое отражение в концепциях постиндустриального (информационного) общества. П. Бурдье, М. Кастельс, У. Бек, П. Штомпка и другие социологи сформировали парадигму исследования социума, в рамках которой акцент переносится с исследования социальных структур на анализ социальных процессов. Если в прежней парадигме, сложившейся под влиянием работ Т. Парсонса и его последователей, общество рассматривалось как система, совокупность социальных институтов, а индивиды - как элементы системы, то в новой парадигме общество как бы утрачивает свой жесткий каркас, приобретая новые характеристики: подвижность, изменчивость, динамизм.

С одной стороны, современное индустриально-информационное общество является обществом безграничных возможностей, обеспечивающим высочайшую производительность труда, создающим все необходимые условия для технического переоснащения производства на базе новейших технологий, развития современных быстродействующих систем коммуникаций и средств связи, накопления и распространения научной, технической и иной важной для жизнедеятельности людей информации. Все это сближает 
страны, создает все необходимые предпосылки для обеспечения устойчивого функционирования информационных сетей и интеграции в мировую рыночную систему.

С другой стороны, для эффективного функционирования этой системы, как обоснованно отмечают авторы, достаточно 20\% наиболее квалифицированных работников, ученых и специалистов планеты. Сегодня они в подавляющей своей части уже интегрированы странами «золотого миллиарда» [4, c. 8].

По мнению экономистов и политиков, глобализация, высокотехнологичные средства связи, низкие транспортные расходы и неограниченная торговля превращают весь мир в единый рынок. Это приводит к ожесточенной глобальной конкуренции, в том числе и на рынке труда.

Важно обратить внимание на изменения системы социальной стратификации и социальной мобильности в современном обществе. Нам важно понять, какие именно факторы определяют статус индивида в современном социуме, какие именно качества востребованы, определяют победу в конкурентной борьбе и насколько они зависят от непосредственных усилий самого индивида.

В прежнем (индустриальном) мире важнейшим фактором, определяющим социальный статус индивида, была его классовая принадлежность, владение собственностью. Н. Е. Тихонова отмечает, что «к концу XX века «растворились» и исчезли не только традиционные «капиталисты» и «рабочие», о которых писал Маркс, и которых неомарксисты активно искали в новых условиях, но и высший класс, средний класс, рабочий класс и бедные, ситуацию с которыми анализировали многие сторонники неовеберианского подхода. Кризис достиг своей зрелой формы и стало ясно, что нужны новые теории, объясняющие ситуацию, сложившуюся в стратификации обществ современного типа» $[5$, c. 14].

В исследованиях социальной стратификации и социальной мобильности ведущим становится ресурсный подход, в рамках которого важнейшим стратифицирующим фактором выступают различного рода ресурсы (активы, капиталы), которыми владеют индивиды. Социологами были выделены и проа- нализированы различные виды капитала экономический, социальный, культурный. П. Бурдье и ряд других социологов выделяют важнейшую роль культурного капитала в современном обществе, который включает в себя не только определенное количество лет обучения или определенный набор общих и специфических знаний и навыков, отражающих в «снятом» виде затраченный на их приобретение труд, но и особенности поведения, включая особенности речи, способность к обучению и многие другие особенности, вытекающие из условий социализации каждого конкретного индивида и отражающие его труд по освоению культурного наследия в процессе социализации. Бурдье прямо приравнивает «инкорпорированный», т. е. ставший неотъемлемой частью данного индивида, «овеществленный» в нем культурный капитал, к традиционному материализованному вовне его капиталу, дающему возможность присвоения «социальной энергии» [1, c. 519].

Важную роль, наряду с культурным капиталом, приобретает также социальный капитал. Социальный капитал Бурдье характеризует как «совокупность реальных или потенциальных ресурсов, связанных с обладанием устойчивой сетью более или менее институционализированных отношений взаимного знакомства и признания» [1, с. 528]. Причем, если культурный капитал включает в себя капитал людей, в кругу которых проходила социализация индивида, в «снятом» виде, то социальный капитал прямо зависит по своему объему и структуре от показателей капитала тех, кто входит в сеть связей данного индивида.

Таким образом, уже не традиционные виды капитала и даже не власть выступают у Бурдье основой стратификации, а различный объем сложного по структуре совокупного капитала индивида.

Для понимания современной системы социального неравенства важной является сформулированная Бурдье идея о том, что ценность ресурсов генерируется ситуацией дефицита, что в «обществе, в котором доступ к средствам присвоения культурного наследия распределен достаточно равномерно, инкорпорированная культура не выступает в качестве культурного капитала и не дает 
дополнительных преимуществ». Прибыль своим владельцам приносит дефицитный культурный капитал [1, с. 524]. Это означает, что в современном обществе преимущество в социальном соперничестве имеют индивиды, не столько обладающие высокой квалификацией, но с высоким творческим потенциалом. Выпускник университета столкнулся с необходимостью послевузовской подготовки и доказывания уникальности своих способностей, в первую очередь - к самостоятельному высокоэффективному творчеству [2]. Если в 1980-е годы высшее образование и занятость в финансовой и управленческой сферах позволяли поддерживать высокий уровень доходов, то в 1990-е годы требования выросли так, что высшее образование перестало гарантировать жизненный успех. Это подтверждается, в частности, историей интернета, который создавался во многом усилиями недоучившихся студентов, т. е. теми, кто не имел даже формального высшего образования, но обладал высоким творческим потенциалом. Это позволило многим из них в короткий срок стать обладателями многомиллионных состояний.

Ведущие современные социологи, такие как Бурдье, Соренсен и Бек, рассматривают знания как важнейший вид ресурсов в современном мире. Кастельс идет дальше и в основу своей концепции социальной стратификации помещает отношение к производству знания и ресурсы, определяющие это отношение [3].

Основной источник дохода в новом обществе - инновации, знания и информация, поэтому непрерывное образование и самосовершенствование становятся ключевым качеством индивида. Новая, основанная на знании, информациональная экономика требует и новой формы труда, способного к «перепрограммированию» в соответствии с бесконечно меняющимися задачами производства. Особое значение приобретает наличие определенного образования, культуры, личностных качеств и т. д. Обладающие этими качествами индивиды образуют новый класс общества, в рамках которого соперничество становится особенно острым.

«Новая система, - подчеркивает М. Кастельс, - характеризуется тенденцией возрастания социального неравенства и поляриза- ции, а именно одновременного роста верхушки - дна социальной шкалы. Этот процесс является результатом трех явлений: 1) фундаментальной дифференциации между самопрограммируемым высокопроизводительным трудом и родовым заменимым трудом; 2) индивидуализации труда, которая подрывает его коллективную организацию, таким образом предоставляя слабейшие сегменты рабочей силы своей судьбе; 3) глобализации экономики и делегитимизации государства, постепенной гибели государства всеобщего благосостояния, лишающей спасательного круга тех людей, которые не могут преуспеть самостоятельно» [3, с. 499].

Следствием становления этой новой социальной системы является то, что новому миру нужны, прежде всего, представители высококвалифицированного труда и, в сравнительно небольшом количестве, - традиционная рабочая сила, к которой относится подавляющее большинство человечества. В современном обществе сложилась ситуация, при которой господствующий класс просто не нуждается в низших классах как объекте эксплуатации и они переходят в состояние эксклюзии, которое социологи обозначают как «угнетение (притеснение) без эксплуатации».

С точки зрения ресурсного подхода можно говорить о принадлежности индивидов в современных условиях даже не к трем разным классам, а к трем самостоятельным мирам - «белому» миру мейнстрима, «серой зоне» высоких рисков и «черной дыре» глубокой эксклюзии, попадая в которую каждый может сказать: «оставь надежду, всяк сюда входящий».

В условиях роста свободы и вариативности жизненных судеб, всевозрастающей индивидуализации, для отдельного человека нет жесткой заданности социальной эксклюзии. Его социальный статус во многом зависит от его собственных усилий. Однако в условиях действия тенденции возрастающей социальной поляризации, когда «новый средний класс» разделяется на высококвалицированных и традиционных работников, возрастает сегмент социально исключенных. В связи с этим особое значение приобретают личностные качества индивида.

Таким образом, в различных термино- 
логических и концептуальных контекстах многие современные социологи обратили внимание на одно и то же явление - превращение в современном обществе многих характеристик индивида, не выступавших еще 50-70 лет назад в массовом масштабе как значимые виды ресурсов, в активы, прямо влияющие на экономическое положение, жизненные шансы и угрожающие индивиду риски.

Огромное значение в изменившихся условиях приобрели новые виды ресурсов, вытекающие из характера социализации, особенностей поведения, общего уровня культуры и т. п. Значимыми оказываются также физиологический (здоровье, возраст, пол), символический, личностный и другие ресурсы.

Нам необходимо учитывать выделенные социологами изменения относительной значимости различного рода ресурсов в обществе. Это позволяет понять, как изменяется характер социального взаимодействия и общество в целом.

\section{Литература}

1. Бурдье П. Формы капитала. // Западная экономическая социология. Хрестоматия современной классики. - М.: РОССПЭН, 2004.

2. Иноземиев В. На рубеже эпох. Экономические тенденции и их неэкономические следствия. - М.: Экономика, 2003.

3. Кастельс М. Информационная эпоха: экономика, общество и культура. - М.: ГУ ВШЭ, 2000.

4. Мартин Г.-П., Шуманн Х. Западня глобализации: атака на процветание и демократию [Электронный ресурс] / Перерождение ради процветания. - Режим доступа: http://marsexxx.com/lit/zapadnya-globalizacii. htm, свободный. - Загл. с экрана.

5. Тихонова H. E. Ресурсный подход как новая теоретическая парадигма в стратификационных исследованиях. // Экономическая социология. - 2006. - №3.

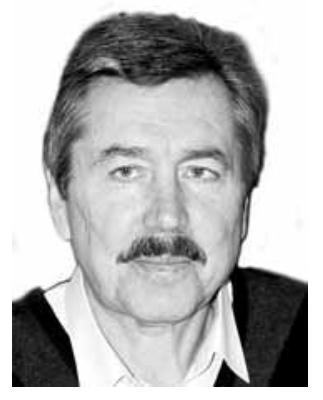

Василий Сергеевич Любченко - доктор философских наук, профессор, заведующий кафедрой философии Южно-российского государственного технического университета (НПИ).

Vasiliy Sergeyevich Lyubchenko - Ph.D., Doctor of Philosophy, professor, head of South Russian State Technical University (NPI) Philosophy department.

346428 , г. Новочеркасск, ул. Просвещения, 132 132 Prosveshcheniya st., 346428, Novocherkassk, Rostov reg., Russia Тел.: +7 (8635) 25-54-27; e-mail: sophiya_npi@mail.ru 